\title{
The ubiquitous interleukin-6: a time for reappraisal
}

Enrique Z Fisman ${ }^{1,2^{*}}$, Alexander Tenenbaum ${ }^{1,2,3}$

\begin{abstract}
Interleukin-6 (IL-6) is a multifunctional cytokine regulating humoral and cellular responses and playing a central role in inflammation and tissue injury. Its effects are mediated through interaction with its receptor complex, IL-6R $\beta$ (also known as gp130). It plays an important role in the pathogenesis of coronary artery disease and large quantities of IL-6 are found in human atherosclerotic plaques. IL-6 levels positively correlate with higher all-cause mortality, unstable angina, left ventricular dysfunction, propensity to diabetes and its complications, hypertension, obesity and several types of cancer. IL-6 levels augmentation demonstrates a remarkable parallel with another biomarkers reflecting harmful processes, like tumor necrosis factor alpha, interleukins 8 and 18, YKL-40, C reactive protein and resistin. Due to these facts, IL-6 was classified as a noxious interleukin. Nonetheless, there are several facts that challenge this usually accepted point of view. Since IL-6 has also anti-inflammatory activity, it seems reasonable to assume that favorable aspects exist. These aspects are two: 1. protection against bacterial infections, inactivating proinflammatory mediators, mitigating the course of septic shock and inducing the production of cortisol; and 2. influence on insulin sensitivity during exercise; this aspect is even more important. During exercise IL-6 is synthesized and released by muscles, with enhanced insulin action immediately at early recovery. Skeletal muscle may be considered as an endocrine organ; contracting muscles produce IL-6 and release it into the blood exerting its effects on other organs. The increase in circulating levels of IL-6 after exercise is consistent and proportional to exercise duration, intensity, muscle mass involved and endurance capacity. Thus, the fascinating possibility that the plenteous beneficial health effects of exercise could be ultimately mediated by IL-6 merits further elucidation. Interleukins were termed "good" or "bad", probably due to a tendency to see things in black and white, with no gray area in between. Calling IL-6 "a molecule with both beneficial and destructive potentials" would be a more equitable approach. In the literary creatures of Dr. Jekyll and Mr. Hyde, a good and an evil personality are found in the same individual. IL-6 playing the role of Dr. Jekyll is emerging; the time for IL-6 reappraisal is coming.
\end{abstract}

Evidence continues to pile during the last two decades regarding the clinical relevance of laboratory predictors of pathophysiological events. These predictors are molecules, usually in the picogram (pg) range, called biomarkers. New and more specific biomarkers are currently isolated employing sophisticated bioinformatics approaches [1,2]. A biomarker is defined as a biochemical characteristic that may be objectively quantified and evaluated as an indicator of normal biological processes, pathogenic events, or responses to pharmacological or other therapeutic interventions. Thus, biomarkers are classified into 3 different types: Type 0 , which estimates the emergence or advance of a disease, Type 1, which measures responses to

\footnotetext{
* Correspondence: zfisman@post.tau.ac.il

'Sackler Faculty of Medicine, Tel-Aviv University, 69978 Tel-Aviv, Israel
}

Full list of author information is available at the end of the article therapeutic interventions, and Type 2, which may be employed as surrogate clinical endpoints $[3,4]$.

In this context, interleukin-6 (IL-6) has gained a leading role. Its popularity is rooted on the fact that it can be defined either as a Type 0,1 or 2 biomarker, depending on the given clinical setting. Thus, overlapping the 3 types of biomarkers, IL- 6 attained a wide use in experimental and clinical studies. IL- 6 is a multifunctional cytokine. It regulates humoral and cellular responses and plays a central role in inflammation and tissue injury. Its effects are mediated through interaction with its receptor complex, IL-6R $\beta$ (also known as gp130) as a signaling subunit. This cytokine plays a very important role in the pathogenesis of coronary artery disease (CAD) [5]. Large quantities of IL-6 are found in human atherosclerotic plaques [6]. IL-6 levels are associated to

\section{() Biomed Central}


higher all-cause mortality in elderly persons [7] and are elevated in patients with unstable angina compared with those with stable disease [8]. Moreover, patients with persistently elevated IL-6 levels demonstrate a worse inhospital outcome following admission with unstable angina $[9,10]$, as well as left ventricular diastolic dysfunction in both clinical trials [11] and experimental animal models [12]. We have also shown that in CAD patients with angina pectoris and/or healed myocardial infarction (MI), a significantly higher risk for future cardiac morbility and mortality was found in the upper IL6 quintile (odds ratio, 3.44; 95\% CI 1.57-8.13) after a mean follow-up period of 6.3 years [13]. IL-6 is also elevated in experimental MI models [14].

Additionally, IL-6 seems to embody a negative role in both main types of diabetes. After adjustment for age, gender, body mass index, waist-to-hip ratio, sports, smoking, alcohol consumption and other variables, IL-6 emerges as an independent early predictor of type 2 diabetes mellitus (T2DM), preceding its clinical onset [15]. Type 1 diabetes mellitus (T1DM) young patients - even in good glycemic control - show higher levels of IL-6 and fibrinogen than controls [16]. It has been shown that postmenopausal women with T1DM present higher serum bioactive IL-6 levels than matched healthy controls [17] and that subjects with diabetic foot show higher IL-6 values in comparison with T2DM patients without diabetic foot complication [18]. Additionally, IL-6 polymorphism seems to be a genetic susceptibility factor for the progression of diabetic nephropathy $[19,20]$.

Besides its roles in the cardiovascular system and in regulation of glucose metabolism, IL-6 ubiquity is astonishing. Secreted by several types of cells, mainly macrophagues and T cells, the pleiotropic IL-6 is related to both immunoregulation and nonimmune physiological traits in most cell types and tissues outside the immune system [21]. Expressing a state of low grade chronic inflammation, IL- 6 augmented levels have been reported to be directly related to the severity of sepsis [22], hypertension [23], poor survival among head and neck cancer patients [24], development of hairy cell leukemia [25], increased breast cancer risk in premenopausal women [26], intensity of inflammatory responses [27-29], obesity [30,31], increased insulin resistance [23,32-34], etc. In addition, IL-6 levels augmentation demonstrates a remarkable parallel with another biomarkers reflecting harmful processes, like tumor necrosis factor alpha (TNF $\alpha)[11,35]$, interleukins 8 and 18 [5,36], YKL-40 [37], C reactive protein (CRP) [38-40], resistin [41], etc. A comprehensive review of IL-6 numerous and complex biological effects is beyond the scope of this article.
Based on the above facts, IL- 6 appears to be involved in a long series of deleterious actions, and it was classified as a noxious or "bad" interleukin $[5,42]$. Nonetheless, there are several facts that challenge this usually accepted point of view. A reconsideration is needed, as detailed hereinafter.

\section{Curtails of interleukin research}

The concept of IL- 6 being a damaging factor has growth mainly on the basis of statistical correlations in clinical studies, in vitro cell culture studies at supraphysiological levels of IL-6 and animal models employing mice [43].

Several important points should be taken into consideration when performing interleukin research: 1) increased levels of a given IL, presenting statistical correlation with disease, does not necessarily imply causation; 2) these compounds are characterized by substantial redundancy in that different interleukins have similar and overlapping functions; 3 ) interleukins may stimulate secretion of other interleukins, enhancing or inhibiting each other; 4) interleukins possess 'paradoxical' effects, expressed as protective properties regarding a given system, whereas they may damage another system, and 5) protective or noxious effects of a given interleukin may be concentration-dependent $[5,42]$.

These general rules also pertain specifically to IL-6. Thus, studies "blaming" IL-6 based on statistical analyses or cell culture at high IL-6 concentrations could be partially biased by the mentioned intrinsic drawbacks. Regarding mice studies, it should be pointed out that comparative genomics research demonstrated that mouse and human IL- 6 share only $42 \%$ aminoacid sequence identity [21]; hence, in this particular case extrapolation of mice findings to humans requires extreme caution.

Another problem that jeopardizes IL- 6 research and may intricate IL- 6 use as a bedside laboratory tool is the variability of its values. The established normal values are $1 \mathrm{pg} / \mathrm{ml}[44,45]$, but they increase at several settings like a single high fat meal [46] physical activity [47], normal menstrual cycle [48], acute hyperglycemia [49] or during and after surgery [50]. Pregnancy represents a good example of this inconsistency: median values of $129 \mathrm{pg} / \mathrm{ml}$ were registered at delivery, decreasing to 58 $\mathrm{pg} / \mathrm{ml}$ immediately afterward [51]. Moreover, during sepsis IL-6 may reach even much more higher values [52].

\section{Beneficial effects}

Besides its proinflammatory properties, IL-6 and IL-6regulated acute-phase proteins show also anti-inflammatory activity $[53,54]$. Then, it seems reasonable to assume that IL-6 is not such a bad guy. We will briefly 
comment two aspects related to IL-6 favorable actions: bacterial infections and its particular influence on insulin sensitivity during exercise.

The protective IL-6 effects in infections were described almost three decades ago. Sometimes the interpretation of the results may be controversial since it is debatable whether in sepsis IL-6 represents an inflammation marker and/or a mediator of immune defense responses. Despite discordant results, some issues seem to be rather consistent. In neonatal mouse models of Group B streptococcal disease IL- 6 decreases TNF $\alpha$ production, as well as the expression of TNF receptors in macrophages [55,56]; exogenous administration of IL- 6 improved survival and complete inhibition of IL-6 resulted in a more rapid mortality [56]. IL-6 inactivates proinflammatory mediators and mitigates the course of septic shock [57]; it also induces the production of adrenocorticotropin and, in turn, cortisol, which is a potent anti-inflammatory hormone [58]. In mice infected with the intracellular pathogen Listeria monocytogenes, recombinant mouse IL-6 injected intraperitoneally before infection protected mice in a dose-dependent manner, resulting in decreased bacterial numbers in the spleen and liver; IL- 6 played a role in early priming of the immune response to infection [59]. Anyway, it must be pointed out that these encouraging results are partially overshadowed by the lack of controlled clinical studies.

The second aspect - insulin metabolism during exercise - is even more important. The overwhelming in vitro findings linking IL-6 to increased insulin resistance may lack clinical relevance as in vivo human studies demonstrate that neither splanchnic glucose output nor isotopic tracer determined endogenous glucose production are increased by acute infusion of recombinant human IL-6 (rhIL-6) [43,60]. During exercise IL-6 is synthesized and released by skeletal muscle [61] and its plasma concentrations may be increased as much as 100-fold [47] - in parallel with the intensity and duration of exercise - this represents a far greater increase than that of any other cytokine that has been measured [61]. In this context, it was shown that IL-6 is rapidly released into the circulation following exercise [47], with enhanced insulin action immediately at early recovery. The improved insulin sensitivity is probably mediated by adenosine monophosphate-activated protein kinase (AMPK) [62,63].

In addition, rhIL-6 infusion during a hyperinsulinemiceuglycemic clamp in healthy humans does not effect the insulin-mediated suppression of endogenous glucose production, while increasing glucose infusion rate [64]. Exercise-induced improvement of insulin sensitivity is mainly a local phenomenon, occurring primarily in the exercised, rather than the rested, muscles. This was confirmed from experiments using both rodent and human models where muscles in only one limb have performed work prior to evaluation of insulin action in both limbs $[63,65]$. In both types of trials the prior exercised leg takes up glucose to a far greater extent and with enhanced insulin sensitivity compared with the rested leg. The changes may be of small magnitude, but over time they become important at the whole body [63].

It has been demonstrated that signaling pathways from contracting muscles to other organs are not solely mediated by the nervous system, since electrical stimulation of paralyzed muscles in spinal-cord-injured patients induces many of the same physiological changes as in neurological healthy individuals [66]. Therefore, it was clear that some humoral factor must exist. IL-6 fulfils the criteria of being that factor, via AMPK activation $[47,54,64]$.

\section{Concluding comment}

One of the more important proofs concerning the crucial importance of IL- 6 emerges from an experimental rodent genetic model dated 3 quinquenniums ago. A targeted disruption of the IL- 6 receptor complex gp130 was performed. Embryos homozygous for the gp130 mutation showed hypoplastic ventricular myocardium, reduced numbers of pluripotential cells - mainly hematopoietic progenitors - anemia and several additional abnormalities. The results indicate that gp130 plays a crucial role in myocardial development and hematopoiesis during embryogenesis [67].

Undesirable effects of IL-6 paharmacological blocking maybe reflected also in a clinical routine setting. In recent years, tocilizumab, a humanized anti-IL-6-receptor monoclonal antibody, was developed and successfully used for the treatment of rheumatoid arthritis and juvenile idiopathic arthritis [68]. Common adverse events of the therapy were gastrointestinal, nasopharyngeal, and upper-respiratory-tract infections. More serious adverse events - an anaphylactoid reaction and a gastrointestinal hemorrhage - were also reported [69]. These events are probably related to IL-6-receptor inhibition.

The key IL-6 positive action is its relationship with physical activity via enhancement of insulin-stimulated glucose disposal in humans in vivo $[64,70]$. Skeletal muscle may then be considered as a newly discovered endocrine organ; contracting muscles produce IL- 6 and release it into the blood $[43,47,71]$ exerting its effects on other organs in a hormone-like fashion. The increase in circulating levels of IL- 6 after exercise is a consistent finding, proportional to exercise duration, intensity of effort, the muscle mass involved in the mechanical work and the endurance capacity [71]. Thus, the fascinating possibility that the plenteous beneficial health effects of 
exercise could be ultimately mediated by IL- 6 merits further elucidation.

Interleukins were termed or classified as "good" or "bad" $[5,13,72]$, probably due to a tendency to see things in black and white, with no gray area in between. Calling IL-6 "a molecule with both beneficial and destructive potentials" [73] would be a more equitable approach. In the literary creatures of Dr. Jekyll and Mr. Hyde, a good and an evil personality are found in the same individual [74]. IL-6 playing the role of Dr. Jekyll is emerging; the time for IL-6 reappraisal is coming.

\section{Abbreviations}

AMPK: monophosphate-activated protein kinase; CAD: coronary artery disease; CRP: C reactive protein; IL-6: interleukin-6; TNF $\alpha$ : tumor necrosis factor alpha; T1DM: type 1 diabetes mellitus; T2DM: type 2 diabetes mellitus.

\section{Acknowledgements}

This work was supported in part by the Cardiovascular Diabetology Research Foundation (RA 58-040-684-1), Holon, Israel.

\section{Author details}

${ }^{1}$ Sackler Faculty of Medicine, Tel-Aviv University, 69978 Tel-Aviv, Israel. ${ }^{2}$ Cardiovascular Diabetology Research Foundation, 58484 Holon, Israel. ${ }^{3}$ Cardiac Rehabilitation Institute, Sheba Medical Center, 52621 Tel-Hashomer, Israel.

\section{Authors' contributions}

Both authors have equally contributed in the conception and drafting of the manuscript. All authors read and approved the final manuscript.

\section{Competing interests}

The authors declare that they have no competing interests.

Received: 1 October 2010 Accepted: 11 October 2010

Published: 11 October 2010

\section{References}

1. Gerszten RE, Wang TJ: The search for new cardiovascular biomarkers. Nature 2008, 51:949-952

2. Steinbrich-Zöllner M, Grün JR, Kaiser T, Biesen R, Raba K, Wu P, Thiel A, Rudwaleit M, Sieper J, Burmester GR, Radbruch A, Grützkau A: From transcriptome to cytome: integrating cytometric profiling, multivariate cluster, and prediction analyses for a phenotypical classification of inflammatory diseases. Cytometry A 2008, 73:333-340.

3. Biomarkers Definitions Working Group: Biomarkers and surrogate endpoints: preferred definitions and conceptual framework. Clin Pharmacol Ther 2001, 69:89-95.

4. Azuaje F, Devaux Y, Wagner D: Computational biology for cardiovascular biomarker discovery. Brief Bioinform 2009, 10:367-377.

5. Fisman EZ, Adler Y, Tenenbaum A: Biomarkers in cardiovascular diabetology: interleukins and matrixins. Adv Cardiol 2008, 45:44-64.

6. Rus HG, Vlaicu R, Niculescu F: Interleukin-6 and interleukin-8 protein and gene expression in human arterial atherosclerotic wall. Atherosclerosis 1996, 127:263-271.

7. Reuben DB, Ferrucci L, Wallace R, Tracy RP, Corti MC, Heimovitz H, Harris TB: The prognostic value of serum albumin in healthy older persons with low and high serum interleukin-6 (IL-6) levels. J Am Geriatr Soc 2000, 48:1404-1407.

8. Biasucci LM, Vitelli A, Liuzzo G, Altamura S, Caligiuri G, Monaco C, Rebuzzi AG, Ciliberto G, Maseri A: Elevated levels of IL-6 in unstable angina. Circulation 1996, 94:874-877.

9. Biasucci LM, Liuzzo G, Grillo RL, Caligiuri G, Rebuzzi AG, Buffon A, Summaria F, Ginnetti F, Fadda G, Maseri A: Elevated levels of C-reactive protein at discharge predicts recurrent instability in patients with unstable angina. Circulation 1999, 99:855-860.
10. Biasucci LM, Liuzzo G, Fantuzzi G, Caligiuri G, Rebuzzi AG, Ginnetti F, Dinarello CA, Maseri A: Increasing levels of interleukin (IL)-1Ra and IL-6 during the first 2 days of hospitalization in unstable angina are associated with increased risk of in-hospital coronary events. Circulation 1999, 99:2079-2084.

11. Dinh W, Füth R, Nickl W, Krahn T, Ellinghaus P, Scheffold T, Bansemir L, Bufe A, Barroso MC, Lankisch M: Elevated plasma levels of TNF-alpha and interleukin-6 in patients with diastolic dysfunction and glucose metabolism disorders. Cardiovasc Diabetol 2009, 8:58.

12. Meléndez GC, McLarty JL, Levick SP, Du Y, Janicki JS, Brower GL: Interleukin 6 mediates myocardial fibrosis, concentric hypertrophy, and diastolic dysfunction in rats. Hypertension 2010, 56:225-231.

13. Fisman EZ, Benderly M, Esper RJ, Behar S, Boyko V, Adler Y, Tanne D, Matas $Z$, Tenenbaum A: Interleukin- 6 and the risk of future cardiovascular events in patients with angina pectoris and/or healed myocardial infarction. Am J Cardiol 2006, 98:14-18.

14. Vahtola E, Louhelainen $M$, Forstén $H$, Merasto S, Raivio J, Kaheinen $P$, Kytö V, Tikkanen I, Levijoki J, Mervaala E: Sirtuin1-p53, forkhead box 03a, p38 and post-infarct cardiac remodeling in the spontaneously diabetic Goto-Kakizaki rat. Cardiovasc Diabetol 2010, 9:5.

15. Spranger J, Kroke A, Möhlig M, Hoffmann K, Bergmann MM, Ristow M, Boeing H, Pfeiffer AF: Inflammatory cytokines and the risk to develop type 2 diabetes: results of the prospective population-based European Prospective Investigation into Cancer and Nutrition (EPIC)-Potsdam Study. Diabetes 2003, 52:812-817.

16. Snell-Bergeon JK, West NA, Mayer-Davis EJ, Liese AD, Marcovina SM, D'Agostino RB Jr, Hamman RF, Dabelea D: Inflammatory markers are increased in youth with type 1 diabetes: the SEARCH Case-Control study. J Clin Endocrinol Metab 2010, 95:2868-2876.

17. Rachon D, Mysliwska J, Suchecka-Rachon K, Semetkowska-Jurkiewicz B, Zorena K, Lysiak-Szydlowska W: Serum interleukin-6 levels and bone mineral density at the femoral neck in postmenopausal women with type 1 diabetes. Diabet Med 2003, 20:475-480.

18. Tuttolomondo A, La Placa S, Di Raimondo D, Bellia C, Caruso A, Lo Sasso B, Guercio G, Diana G, Ciaccio M, Licata G, Pinto A: Adiponectin, resistin and IL-6 plasma levels in subjects with diabetic foot and possible correlations with clinical variables and cardiovascular co-morbidity. Cardiovasc Diabetol 2010, 9:50.

19. Kitamura A, Hasegawa G, Obayashi H, Kamiuchi K, Ishii M, Yano M, Tanaka T, Yamaguchi M, Shigeta H, Ogata M, Nakamura N, Yoshikawa T: Interleukin-6 polymorphism (-634C/G) in the promotor region and the progression of diabetic nephropathy in type 2 diabetes. Diabet Med 2002, 19:1000-1005.

20. Burkhardt K, Schwarz S, Pan C, Stelter F, Kotliar K, Von Eynatten M, Sollinger D, Lanzl I, Heemann U, Baumann M: Myeloid-related protein 8/14 complex describes microcirculatory alterations in patients with type 2 diabetes and nephropathy. Cardiovasc Diabetol 2009, 8:10.

21. Kamimura D, Ishihara K, Hirano T: IL-6 signal transduction and its physiological roles: the signal orchestration model. Rev Physiol Biochem Pharmacol 2003, 149:1-38.

22. Andrejko KM, Chen J, Deutschman CS: Intrahepatic STAT-3 activation and acute phase gene expression predict outcome after CLP sepsis in the rat. Am J Physiol 1998, 275:G1423-G1429.

23. Fernández-Real JM, Vayreda M, Richart C, Gutierrez C, Broch M, Vendrell J, Ricart W: Circulating interleukin 6 levels, blood pressure, and insulin sensitivity in apparently healthy men and women. J Clin Endocrinol Metab 2001, 86:1154-1159.

24. Duffy SA, Taylor JM, Terrell JE, Islam M, Li Y, Fowler KE, Wolf GT, Teknos TN: Interleukin-6 predicts recurrence and survival among head and neck cancer patients. Cancer 2008, 113:750-757.

25. Barut B, Chauhan D, Uchiyama H, Anderson KC: Interleukin-6 functions as an intracellular growth factor in hairy cell leukemia in vitro. $J$ Clin Invest 1993, 92:2346-2352.

26. Alokail MS, Al-Daghri NM, Al-Attas OS, Hussain T: Combined effects of obesity and type 2 diabetes contribute to increased breast cancer risk in premenopausal women. Cardiovasc Diabetol 2009, 8:33.

27. Gauldie J, Northemann W, Fey GH: IL-6 functions as an exocrine hormone in inflammation. Hepatocytes undergoing acute phase responses require exogenous IL-6. J Immunol 1990, 15(144):3804-3808.

28. Peters $M$, Jacobs $S$, Ehlers $M$, Vollmer $P$, Müllberg J, Wolf E, Brem $G$, Meyer zum Büschenfelde $\mathrm{KH}$, Rose-John $\mathrm{S}$ : The function of the soluble 
interleukin 6 (IL-6) receptor in vivo: sensitization of human soluble IL-6 receptor transgenic mice towards IL- 6 and prolongation of the plasma half-life of IL-6. J Exp Med 1996, 183:1399-1406.

29. Cuschieri J, Bulger E, Schaeffer V, Sakr S, Nathens AB, Hennessy L, Minei J, Moore EE, O'Keefe G, Sperry J, Remick D, Tompkins R, Maier RV, Inflammation and the Host Response to Injury Collaborative Research Program: Early elevation in random plasma IL- 6 after severe injury is associated with development of organ failure. Shock 2010, 34:346-351.

30. Roytblat L, Rachinsky M, Fisher A, Greemberg L, Shapira Y, Douvdevani A, Gelman S: Raised interleukin-6 levels in obese patients. Obes Res 2000, 8:673-675.

31. Pou KM, Massaro JM, Hoffmann U, Vasan RS, Maurovich-Horvat $P$, Larson MG, Keaney JF Jr, Meigs JB, Lipinska I, Kathiresan S, Murabito JM, O'Donnell CJ, Benjamin EJ, Fox CS: Visceral and subcutaneous adipose tissue volumes are cross-sectionally related to markers of inflammation and oxidative stress: the Framingham Heart Study. Circulation 2007, 116:1234-1241

32. Senn JJ, Klover PJ, Nowak IA, Mooney RA: Interleukin-6 induces cellular insulin resistance in hepatocytes. Diabetes 2002, 51:3391-3399.

33. Bastard JP, Maachi M, Van Nhieu JT, Jardel C, Bruckert E, Grimaldi A, Robert JJ, Capeau J, Hainque B: Adipose tissue IL-6 content correlates with resistance to insulin activation of glucose uptake both in vivo and in vitro. J Clin Endocrinol Metab 2002, 87:2084-2089.

34. Rotter $V$, Nagaev I, Smith U: Interleukin-6 (IL-6) induces insulin resistance in 3T3-L1 adipocytes and is, like IL-8 and tumor necrosis factor- $a$, overexpressed in human fat cells from insulin-resistant subjects. J Biol Chem 2003, 278:45777-45784.

35. Hung J, McQuillan BM, Chapman CM, Thompson PL, Beilby JP: Elevated interleukin-18 levels are associated with the metabolic syndrome independent of obesity and insulin resistance. Arterioscler Thromb Vasc Biol 2005, 25:1268-73.

36. Trøseid M, Seljeflot I, Arnesen H: The role of interleukin-18 in the metabolic syndrome. Cardiovasc Diabetol 2010, 9:11.

37. Rathcke CN, Vestergaard H: YKL-40-an emerging biomarker in cardiovascular disease and diabetes. Cardiovasc Diabetol 2009, 8:61.

38. Heikkilä K, Ebrahim S, Rumley A, Lowe G, Lawlor DA: Associations of circulating C-reactive protein and interleukin- 6 with survival in women with and without cancer: findings from the British Women's Heart and Health Study. Cancer Epidemiol Biomarkers Prev 2007, 16:1155-1159.

39. Knudsen EC, Seljeflot I, Michael A, Eritsland J, Mangschau A, Müller C, Arnesen $H$, Andersen G $\varnothing$ : Increased levels of CRP and MCP-1 are associated with previously unknown abnormal glucose regulation in patients with acute STEMI: a cohort study. Cardiovasc Diabetol 2010, 9:47.

40. Ley SH, Hegele RA, Connelly PW, Harris SB, Mamakeesick M, Cao H, Gittelsohn J, Retnakaran R, Zinman B, Hanley AJ: Assessing the association of the HNF1A G319S variant with C-reactive protein in Aboriginal Canadians: a population-based epidemiological study. Cardiovasc Diabetol 2010, 9:39.

41. Osawa H, Doi Y, Makino H, Ninomiya T, Yonemoto K, Kawamura R, Hata J, Tanizaki $Y$, lida M, Kiyohara Y: Diabetes and hypertension markedly increased the risk of ischemic stroke associated with high serum resistin concentration in a general Japanese population: the Hisayama Study. Cardiovasc Diabetol 2009, 8:60.

42. Fisman EZ, Motro M, Tenenbaum A: Cardiovascular diabetology in the core of a novel interleukins classification: the bad, the good and the aloof. Cardiovasc Diabetol 2003, 2:11.

43. Pedersen BK, Febbraio MA: Point: Interleukin- 6 does have a beneficial role in insulin sensitivity and glucose homeostasis. J Appl Physio/ 2007, 102:814-816.

44. D'Auria L, Bonifati C, Mussi A, D'Agosto G, De Simone C, Giacalone B, Ferraro C, Ameglio $F$ : Cytokines in the sera of patients with pemphigus vulgaris: interleukin-6 and tumour necrosis factor-alpha levels are significantly increased as compared with healthy subjects and correlate with disease activity. Eur Cytokine Netw 1997, 8:383-387.

45. Yamamura M, Yamada Y, Momita S, Kamihira S, Tomonaga M: Circulating interleukin-6 levels are elevated in adult T-cell leukaemia/lymphoma patients and correlate with adverse clinical features and survival. $\mathrm{Br} J$ Haematol 1998, 100:129-134.

46. Mathew M, Tay E, Cusi K: Elevated plasma free fatty acids increase cardiovascular risk by inducing plasma biomarkers of endothelial activation, myeloperoxidase and PAI-1 in healthy subjects. CardiovasC Diabetol 2010, 9:9

47. Febbraio MA, Pedersen BK: Muscle-derived interleukin-6: mechanisms for activation and possible biological roles. FASEB J 2002, 16:1335-1347.

48. Angstwurm MW, Gartner R, Ziegler-Heitbrock HW: Cyclic plasma IL-6 levels during normal menstrual cycle. Cytokine 1997, 9:370-374.

49. Node K, Inoue T: Postprandial hyperglycemia as an etiological factor in vascular failure. Cardiovasc Diabetol 2009, 8:23

50. Sakamoto K, Arakawa H, Mita S, Ishiko T, Ikei S, Egami H, Hisano S, Ogawa M: Elevation of circulating interleukin 6 after surgery: factors influencing the serum level. Cytokine 1994, 6:181-186.

51. Keski-Nisula L, Hirvonen MR, Roponen M, Heinonen S, Pekkanen J: Spontaneous and stimulated interleukin- 6 and tumor necrosis factoralpha production at delivery and three months after birth. Eur Cytokine Netw 2004, 15:67-72.

52. Kitanovski L, Jazbec J, Hojker S, Gubina M, Derganc M: Diagnostic accuracy of procalcitonin and interleukin- 6 values for predicting bacteremia and clinical sepsis in febrile neutropenic children with cancer. Eur J Clin Microbiol Infect Dis 2006, 25:413-415.

53. Tilg H, Dinarello CA, Mier JW: IL-6 and APPs: anti-inflammatory and immunosuppressive mediators. Immunol Today 1997, 18:428-432.

54. Petersen AM, Pedersen BK: The anti-inflammatory effect of exercise. $J$ Appl Physiol 2005, 98:1154-1162.

55. Bermudez LE, Wu M, Petrofsky M, Young LS: Interleukin-6 antagonizes tumor necrosis factor-mediated mycobacteriostatic and mycobactericidal activities in macrophages. Infect Immun 1992, 60:4245-4252.

56. Mancuso G, Tomasello F, Migliardo M, Delfino D, Cochran J, Cook JA, Teti G: Beneficial effects of interleukin- 6 in neonatal mouse models of group $B$ streptococcal disease. Infect Immun 1994, 62:4997-5002.

57. van Vugt $H$, van Gool L, de Ridder L: Alpha 2 macroglobulin of the rat and acute phase protein, mitigates the early course of endotoxin shock. Br J Exp Pathol 1986, 67:313-319.

58. Woloski BM, Smith EM, Meyer WJ, Fuller GM, Blalock JE: Corticotropinreleasing activity of monokines. Science 1985, 230:1035-1037.

59. Liu Z, Simpson RJ, Cheers C: Recombinant interleukin-6 protects mice against experimental bacterial infection. Infect Immun 1992, 60:4402-4406.

60. Steensberg A, Fischer CP, Sacchetti M, Keller C, Osada T, Schjerling P, van Hall G, Febbraio MA, Pedersen BK: Acute interleukin-6 administration does not impair muscle glucose uptake or whole body glucose disposal in healthy humans. J Physiol 2003, 548:631-638.

61. Keller P, Keller C, Carey AL, Jauffred S, Fischer CP, Steensberg A, Pedersen BK: Interleukin-6 production by contracting human skeletal muscle: autocrine regulation by IL-6. Biochem Biophys Res Commun 2003, 310:550-554.

62. Kelly M, Keller C, Avilucea PR, Keller P, Luo Z, Xiang X, Giralt M, Hidalgo J, Saha AK, Pedersen BK: AMPK activity is diminished in tissues of the IL-6 knockout mice: the effect of exercise. Biochem Biophys Res Commun 2004, 320:449-454

63. Wojtaszewski JF, Jorgensen SB, Frosig C, Macdonald C, Birk JB, Richter EA: Insulin signalling: effects of prior exercise. Acta Physio/ Scand 2003, 178:321-328.

64. Carey AL, Steinberg GR, Macaulay SL, Thomas WG, Holmes AG, Ramm G, Prelovsek O, Hohnen-Behrens C, Watt MJ, James DE, Kemp BE, Pedersen BK, Febbraio MA: IL-6 increases insulin stimulated glucose disposal in humans and glucose uptake and fatty acid oxidation in vitro via AMPK. Diabetes 2006, 55:2688-2697.

65. Richter EA, Mikines KJ, Galbo $H$, Kiens B: Effect of exercise on insulin action in human skeletal muscle. J App/ Physiol 1989, 66:876-885.

66. Mohr T, Andersen JL, Biering-Sørensen F, Galbo H, Bangsbo J, Wagner A Kjaer M: Long-term adaptation to electrically induced cycle training in severe spinal cord injured individuals. Spinal Cord 1997, 35:1-16.

67. Yoshida K, Taga T, Saito M, Suematsu S, Kumanogoh A, Tanaka T, Fujiwara H, Hirata M, Yamagami T, Nakahata T, Hirabayashi T, Yoneda Y, Tanaka K, Wang W-Z, Mori C, Shiota K, Yoshida N, Kishimoto T: Targeted disruption of gp130, a common signal transducer for the interleukin 6 family of cytokines, leads to myocardial and hematological disorders. Proc Natl Acad Sci 1996, 93:407-411.

68. Hennigan S, Kavanaugh A: Interleukin-6 inhibitors in the treatment of rheumatoid arthritis. Ther Clin Risk Manag 2008, 4:767-775. 
69. Yokota S, Imagawa T, Mori M, Miyamae T, Aihara Y, Takei S, Iwata N, Umebayashi H, Murata T, Miyoshi M, Tomiita M, Nishimoto N, Kishimoto T: Efficacy and safety of tocilizumab in patients with systemic-onset juvenile idiopathic arthritis: a randomised, double-blind, placebocontrolled, withdrawal phase III trial. Lancet 2008, 371:998-1006.

70. Petersen AM, Pedersen BK: The role of IL- 6 in mediating the antiinflammatory effects of exercise. J Physiol Pharmacol 2006, 57(Suppl 10):43-51.

71. Pedersen BK, Fischer CP: Beneficial health effects of exercise-the role of IL-6 as a myokine. Trends Pharmacol Sci 2007, 28:152-156.

72. Kristiansen OP, Mandrup-Poulsen T: Interleukin-6 and diabetes: the good, the bad, or the indifferent? Diabetes 2005, 54(Suppl 2):S114-124.

73. Gadient RA, Otten UH: Interleukin-6 (IL-6) - a molecule with both beneficial and destructive potentials. Prog Neurobiol 1997, 52:379-90.

74. Stevenson RL: Strange case of Dr Jekyll and Mr Hyde. Plattsburgh, NY: Tundra Books Inc 2008

doi:10.1186/1475-2840-9-62

Cite this article as: Fisman and Tenenbaum: The ubiquitous interleukin6: a time for reappraisal. Cardiovascular Diabetology 2010 9:62.

\section{Submit your next manuscript to BioMed Central and take full advantage of:}

- Convenient online submission

- Thorough peer review

- No space constraints or color figure charges

- Immediate publication on acceptance

- Inclusion in PubMed, CAS, Scopus and Google Scholar

- Research which is freely available for redistribution

Submit your manuscript at www.biomedcentral.com/submit 